\title{
Endometrioma masquerading an ovarian carcinoma
}

\author{
Amanat Sidhu' ${ }^{1}$, Ripan Bala ${ }^{1}$, Pooja Tandon ${ }^{2 *}$, Rajdeep Chhina ${ }^{3}$
}

\author{
${ }^{1}$ Department of Obstetrics and Gynaecology, SGRD Medical College, Amritsar, Punjab, India \\ ${ }^{2}$ Department of Obstetrics and Gynaecology, DMCH, Ludhiana, Punjab, India \\ ${ }^{3}$ Department of Radiology, DMCH, Ludhiana, Punjab, India
}

Received: 22 December 2020

Accepted: 01 February 2021

\author{
*Correspondence: \\ Dr. Pooja Tandon, \\ E-mail: drpoojatandon77@gmail.com
}

Copyright: (c) the author(s), publisher and licensee Medip Academy. This is an open-access article distributed under the terms of the Creative Commons Attribution Non-Commercial License, which permits unrestricted non-commercial use, distribution, and reproduction in any medium, provided the original work is properly cited.

\begin{abstract}
Endometriosis is the presence of endometrial tissue outside the uterus. Endometriosis affects 10-15\% of all women in reproductive age group and $70 \%$ of the women with chronic pelvic pain. The risk of malignant transformation in an endometrioma has been reported to be low, though there is an increased risk for certain gynecological as well as nongynecological carcinomas with endometriosis. We present a case diagnosed as having endometrioma transforming into a malignant tumor in a young female. We intend to emphasize that all the clinicians should make their patients aware of the malignant potential of endometriosis and a strict follow up of all cases being treated conservatively should be a must.
\end{abstract}

Keywords: Endometrioma, Ovarian, Cancer

\section{INTRODUCTION}

Endometriosis is the presence of endometrial tissue outside the uterus. Endometriosis affects $10-15 \%$ of all women in reproductive age group and $70 \%$ of the women with chronic pelvic pain., ${ }^{1,2}$ The risk of malignant transformation in an endometrioma has been reported to be low, though there is an increased risk for certain gynecological as well as non-gynecological carcinomas with endometriosis. We present a case diagnosed as having endometrioma transforming into a malignant tumor in a young female.

\section{CASE REPORT}

A 26 years old, unmarried female presented in the gynecology out patient department with complaints of menstrual irregularities, dysmenorrhea and heaviness in the lower abdomen for four months. On ultrasound, there was a complex right adnexal mass measuring $5.0 \times 4.9 \mathrm{~cm}$, unilocular cyst with ground glass echogenicity suggestive of endometrioma.
Ca 125 was 57 IU/ml, LDH 308 U/L, CEA-1.54 ng/ml, AFP-2.58 ng/ml, B-HCG-1.2 mIU/ml, TSH $3.5 \mathrm{mIU} / \mathrm{ml}$, HB-13.3 g/dl.

Patient was already taking low dose oral contraceptive pills for one month and was tolerating it well. She was advised to continue same treatment for three months and to get her sonogram and CA 125 levels repeated after three months. Patient was lost to follow up, continued taking OCPs herself and presented 3 years later with abdominal distension and mass per abdomen. The mass seemed to be arising from the pelvis and was extending up to the umbilicus. Ultrasound was suggestive of a large right ovarian complex cyst, unilocular with homogenous echogenicity, measuring $22 \times 18 \times 10 \mathrm{~cm}$, uterus normal shape and size. CA125 was $3458 \mathrm{IU} / \mathrm{ml}$. The patient underwent staging laparotomy and a large right ovarian tumor measuring $20 \times 18 \times 10 \mathrm{~cm}$ was removed. The tumor was arising from the right adnexa, was adherent to the intestines, had variegated appearance but the capsule was intact with smooth surface, well defined margins. On cut section, tumor was of variable consistency with $3 / 4$ of 
tumor was cystic and 1/4 solid in consistency. The uterus and the left tube and ovary were normal in appearance. Frozen section from the tumor was suggestive of borderline tumor. Peritoneal aspirate was obtained and sent for cytology. Complete omentectomy was carried out and biopsy was taken from the left ovary. The attendants were informed about the operative findings and decision for fertility preserving surgery was taken awaiting histopathology report. Peritoneal aspirate was negative for malignant cells.

HPE of the tumor showed papillary serous cyst adenocarcinoma ovary, omentum was free of tumor, the biopsy from the left ovary had normal tissue. The patient was counseled to undergo completion surgery and chemotherapy in view of known highly aggressive behavior of the disease. Patient opted to undergo chemotherapy first and is undergoing the same.

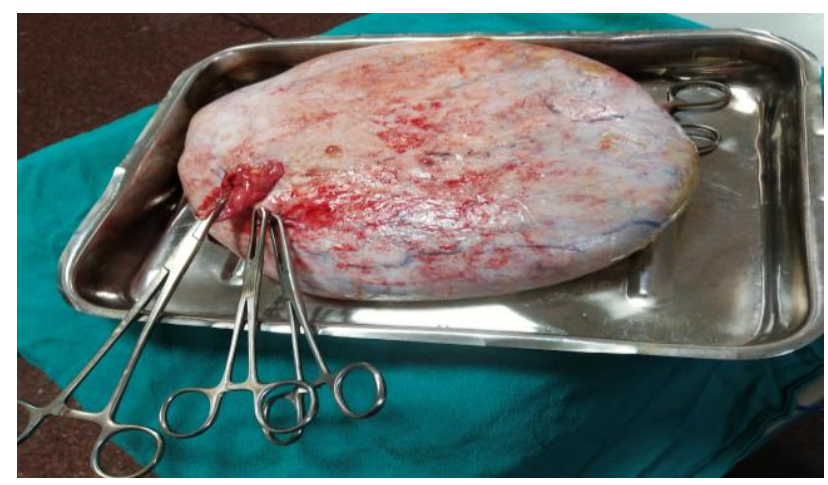

Figure 1: Gross appearance: $20 \times 18 \times 10 \mathrm{~cm}$ tumor with smooth surface, intact capsule.

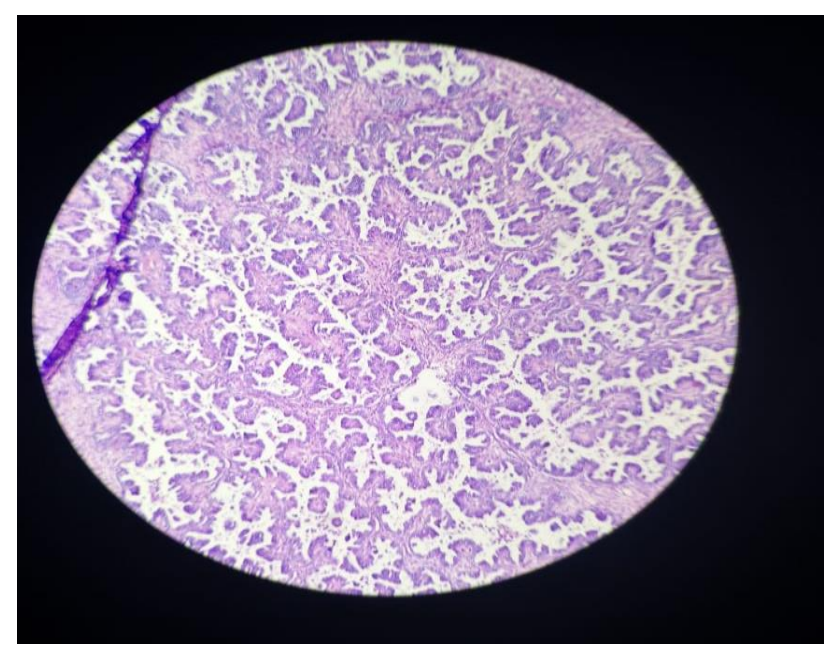

Figure 2: Histopathology: papillary serous cyst adenocarcinoma ovary.

\section{DISCUSSION}

Endometriosis is a chronic, benign gynecological disease affecting women in reproductive age group. Data from large cohort and case control studies indicate a possibly increased risk of various malignancies, especially ovarian cancers with endometriosis. ${ }^{3}$ Histopathological, the most common subtype of ovarian cancer found associated is the high-grade serous cancer $(70 \%)$, followed by the endometrioid (10\%) and clear cell (10\%) type. ${ }^{4}$ Malignant transformation in an endometrioma is a rare occurrence and is estimated to occur in $0.6-0.8 \%$ of women with ovarian endometriosis. ${ }^{5}$ Presently, there are no clinical or diagnostic markers to predict the risk of malignant transformation in an endometrioma. Clinicians should make the patients aware of the malignant potential of the disease and the need to have a strict follow up of patients diagnosed as having endometrioma should be emphasized upon.

\section{CONCLUSION}

Malignant transformation in an endometrioma is rare but is known to happen. Patients with endometriosis being managed medically should be followed up strictly.

\section{Funding: No funding sources Conflict of interest: None declared Ethical approval: Not required}

\section{REFERENCES}

1. Giudice LC, Kao LC. Endometriosis. Lancet. 2004;364:9447:P1789-99.

2. Carter JE. The Journal of the American Association of Gynecologic Laparoscopists. 1994;2(1):43-7.

3. Parazzini F. Association between endometriosis and cancer. A comprehensive review and a critical analysis of clinical and epidemiological evidence. Gynecol Oncol. 2006;101(2):331-41.

4. Krawczyk N, Banys-Paluchowski M, Schmidt D, Ulrich U, Fehm T. Endometriosis-associated Malignancy. Geburtshilfe Frauenheilkd. 2016;76(2):176-81.

5. Stern RC, Dash R, Bentley RC, Snyder MJ, Haney AF, Robboy S. Malignancy in Endometriosis: Frequency and Comparison of Ovarian and Extraovarian Types. J Int J Gynecol Pathol. 2001;20(2):133-9.

Cite this article as: Sidhu A, Bala1 R, Tandon P, Chhina R. Endometrioma masquerading an ovarian carcinoma. Int J Reprod Contracept Obstet Gynecol 2021;10:1205-6. 